\title{
Anxiety in children with autism at school: A systematic review
}

Short title: Anxiety in autism in school settings

Dawn Adams ${ }^{1,2}$ Kate Young, ${ }^{, 2}$ and Deb Keen ${ }^{1,2}$

\author{
${ }^{1}$ Autism Centre of Excellence, Griffith University, Messines Ridge Road, Mt Gravatt, \\ Brisbane, QLD 4122, Australia \\ ${ }^{2}$ Griffith Institute for Educational Research, Griffith University, Messines Ridge Road, Mt \\ Gravatt, Brisbane, QLD 4122, Australia
}

\section{Funding statement}

This review was supported by an Educational Horizons Grant from the Queensland Department of Education and Training. The funder had no role in the study design, collection, analysis or interpretation of the data, writing the manuscript, or the decision to submit the paper for publication.

\section{Declaration of conflicting interests}

Dawn Adams declares that she has no conflict of interest.

Kate Young declares that she has no conflict of interest.

Deb Keen declares that she has no conflict of interest. 
Correspondence regarding this article should be addressed to:

Dr Dawn Adams,

Autism Centre of Excellence,

School of Education and Professional Studies,

Griffith University,

Mt Gravatt,

Brisbane, QLD 4122,

Australia

Telephone: +61(0) 737355854

Email: Dawn.Adams@griffith.edu.au

\section{Acknowledgments}

The authors gratefully acknowledge the work of Damian Vann in assisting with the inter-rater reliability and the assistance and support of the Griffith Institute for Educational Research (GIER). 


\begin{abstract}
Anxiety in autism is commonly reported by parents, but teacher reports of anxiety in their students with autism has received little attention. This paper presents the results from the first systematic review on anxiety in children with autism at school. Six intervention studies (five of which were based upon Cognitive-Behavioural Therapy) and 26 descriptive studies met inclusion criteria. Sample populations from included studies were frequently drawn from psychiatric clinics, with females and children attending special schools underrepresented, making generalisability of results difficult. Few studies used anxiety-specific measures, with most reporting anxiety-related subscales means from broader emotional/behavioural questionnaires. While 19 studies included multiple informants, which is recommended practice, only seven studies combined parent, teacher, and child reports of anxiety. Comparison between informants proved difficult, with varying sample sizes and few studies using the same measure across participant groups. To further our understanding of the presentation of anxiety in children with autism attending school, studies need to include multiple informants and where possible, extend beyond reporting average scores from broad anxiety subscales to provide descriptions of presentation and symptomatology.
\end{abstract}

\title{
Keywords
}

autism, anxiety, mental health, school, systematic review 


\title{
Anxiety in children with autism at school: A systematic review
}

Short Title: Anxiety in autism in school settings

\begin{abstract}
Anxiety in autism is commonly reported by parents, but teacher reports of anxiety in their students with autism has received little attention. This paper presents the results from the first systematic review on anxiety in children with autism at school. Six intervention studies (five of which were based upon Cognitive-Behavioural Therapy) and 26 descriptive studies met inclusion criteria. Sample populations from included studies were frequently drawn from psychiatric clinics, with females and children attending special schools underrepresented, making generalisability of results difficult. Few studies used anxiety-specific measures, with most reporting anxiety-related subscales means from broader emotional/behavioural questionnaires. While 19 studies included multiple informants, which is recommended practice, only seven studies combined parent, teacher, and child reports of anxiety. Comparison between informants proved difficult, with varying sample sizes and few studies using the same measure across participant groups. To further our understanding of the presentation of anxiety in children with autism attending school, studies need to include multiple informants and where possible, extend beyond reporting average scores from broad anxiety subscales to provide descriptions of presentation and symptomatology.
\end{abstract}

\section{Keywords}

autism, anxiety, mental health, school, systematic review 


\section{Anxiety in children with autism at school: A systematic review}

Anxiety and worries were reported in a number of Leo Kanner's (1943) original case study descriptions of children with autism. However, it is only relatively recently that research has focused upon this area, with a six-fold increase in papers published on the topic from 2005 to 2015 (Vasa, Keefer, Reaven, South \& White, 2018). Anxiety disorders are now recognised as the most commonly co-occurring conditions within autism spectrum disorders, with meta-analyses suggesting prevalence rates of clinically significant anxiety of approximately $40 \%$ (van Steensel, Bogels \& Perrin, 2011), compared to $13.4 \%$ of children worldwide without autism (Polanczyk, Salum, Sugaya, Caye \& Rohde, 2015). There is growing research to suggest that anxiety can exacerbate autism symptoms. Further, the relationship between anxiety and autism characteristics or profiles may be bidirectional (e.g., White et al., 2014), suggesting that the presence of anxiety may not only contribute to difficulties, but also be a consequence of social and academic difficulties associated with autism characteristics.

It is known that anxiety can impact on school performance for the children without a diagnosis of autism, but research on the impact of anxiety on academic achievement for students with autism has been limited. It is evident, however, that children with autism are generally at risk of academic underachievement (see review by Keen, Webster \& Ridley, 2016) and participate in less school activities than expected for children their age (Simpson, Keen, Adams, Alston-Knox \& Roberts, 2018). It has been suggested that anxiety may be one of the barriers to successful school functioning in children with autism (Wood \& Gadow, 2010) and that anxiety symptomatology may be present in children with autism at the age they begin school (Adams, Simpson \& Keen, 2018; Keen, Adams, Simpson, den Houting \& Roberts, 2017). The impact of autism and anxiety on the classroom has been noted by teachers, other professionals and parents, with anxiety being identified in the top three factors 
affecting school participation and the top two factors influencing classroom support needs (Saggers et al., 2016).

Given the importance anxiety may play in the school context and on educational outcomes, research focussing upon anxiety within the school setting would seem particularly important. To advance our understanding of school anxiety, it is important to gain the teacher's perspective on anxiety, particularly given recent suggestions that the presentation of anxiety symptomatology may differ between home, school and community settings (Adams, Young, Simpson \& Keen, 2018). Input from teachers can be valuable as they spend a lot of time with children and are likely to see them in different, potentially anxiety-provoking situations compared to those observed by parents or primary caregivers (Lyneham, Street, Abbott \& Rapee, 2008). However, the majority of studies exploring anxiety in children with autism have to date relied solely on parent report (e.g., van Steensel et al., 2011). Parents may have only a limited knowledge of how anxiety may present for their child with autism at school, so gaining information from multiple informants across different contexts has the potential to provide a more comprehensive profile of anxiety and behaviour for students on the spectrum. For this and a number of other reasons, the use of multiple informants is recommended practice (Schniering, Hudson \& Rapee, 2000).

Studies using multiple informants with typically developing children note frequent variability in informant agreement levels for internalizing disorders such as anxiety (Achenbach, McConaughy \& Howell, 1987; De Los Reyes et al., 2015), especially when ratings are provided across different settings with different demands and expectations (e.g., home and school). This variability has led to discussion around the possibility of differing presentations of anxiety symptomatology across settings. However, such multi-informant explorations are limited in autism, restricting the extent to which we are able to understand how anxiety may present at school compared with home and community contexts. Such 
information could be critical to help teachers identify anxiety in children with autism in their class and therefore instigate referral to evidence-based interventions to reduce anxiety within this setting.

So as to better understand how anxiety may present in children with autism in the school context, the aim of this study was to identify and review research that has focused upon anxiety in children with autism in the school setting. The following research questions were posed:

1) What studies have reported upon anxiety in children with autism in the school setting?

2) Which measures have been used to report levels of anxiety in children with autism at school?

3) Is there concordance between the scores on teacher measures of anxiety with those completed by children on the autism spectrum and/or their parents?

\section{Method}

The protocol for this systematic review was registered online with PROSPERO, an international register for systematic reviews with health-related outcomes (Registration number: CRD42017081739). Preferred Reporting Items for Systematic Reviews and MetaAnalyses (PRISMA) standards were followed for all stages of this systematic review.

\section{Eligibility criteria}

It is recommended (e.g., by COSMIN) to focus searches on a well-defined group and outcome. Therefore, the inclusion and exclusion criteria for this review required studies specifically to have at least a subscale of a measure or an intervention focusing upon anxiety (rather than broader emotional functioning) in children with autism in the school setting. Studies were included within this literature review if they met the following inclusion criteria: (a) study must report on anxiety in children within the school environment (including mainstream schools, special schools or specialist educational settings, either publicly or 
privately funded); (b) study focuses upon, measures, or describes the child's anxiety or anxiety symptomatology; (c) study must involve a sample of humans with autism with a mean age between 5 and 17 years; (d) autism diagnosis must be established through a reliable measure of autism (e.g., Autism Diagnostic Interview-Revised (ADI-R), Autism Diagnostic Observational Schedule (ADOS), and/or through educational or medical records); and (e) if there is a mixed-diagnosis or mixed-age sample, the anxiety data for the autism group of interest are reported separately. Reviews, opinions, dissertations, editorials, book chapters, and descriptive pieces were not included in this systematic review. Case studies, single case designs and single subject design studies were also excluded because of the high risk of bias in this design and/or the possible lack of generalisability and representation of a case study to a broader population. This decision was taken in order to include as many studies as possible without jeopardising internal or external validity.

\section{Search strategy}

The electronic databases ERIC, MEDLINE, PsycINFO, and Web of Science were searched during October 2017. The Cochrane library and PROSPERO database was also searched to confirm that no other systematic reviews of the current study topic existed or were registered as being in progress. The search was restricted to articles in English and those published after 1994, when Asperger's disorder was entered into the DSM-IV. The search strategy included terms pertaining to autism, anxiety, and school (see Table 1).

$$
++ \text { Insert Table } 1 \text { about here++ }
$$

\section{Review strategy}

Electronic searches resulted in 10,598 records being identified (see Figure 1). Following removal of duplicates, the titles and abstracts of 8,139 articles were assessed against inclusion criteria by the primary rater, and a random sample of $20 \%$ was double reviewed by a second rater who was blind to the other researcher's ratings. This is accepted 
practice when a review is large and resources are limited (Petticrew \& Roberts, 2006). The double reviewing resulted in a $99.3 \%$ agreement. The 11 articles where the ratings differed were discussed and a consensus agreement was reached for two of the papers. A third rater was consulted for the remaining nine $(0.6 \%)$ papers.

Where inclusion or exclusion could not be determined by the title and abstract alone, the full text was assessed by a primary rater and, with a random sample of $20 \%$, double reviewed by a second rater blind to the other researcher's ratings. There were no disagreements at this stage. All papers which met inclusion criteria were double rated and data were extracted by two independent raters. In addition, once studies were identified, an ancestral search was conducted of reference lists to ensure no relevant research had been missed. No additional studies were found, leaving 32 studies that met the criteria for the current review.

\section{Insert Figure 1 about here}

\section{Data extraction and synthesis}

Data were independently extracted by two authors and disagreements were resolved by both authors revisiting the article and discussing the information presented. There were no cases where a third reviewer was required to resolve disagreements. For each paper, information recorded included details of the research team (including geographical location of study), study design (intervention or observational), sample characteristics (of both the autism sample and any control or comparison groups), and measure of anxiety (completed by teacher, parent, and/or student). If the study described an intervention, the interventions used, location, and numbers of sessions were also recorded.

To assess the extent to which the priori decision to exclude case studies and series may have impacted upon the results of the review, all case studies and series were identified and checked against the additional exclusion criteria. The systematic review had originally 
identified 171 case studies, all of which would be excluded for other reasons other than sample size (five were focussed outside of the school setting, four had participant ages outside 5-17 years, one was not a data based study, 127 did not include a measure of anxiety or did not focus upon anxiety, 10 studies did not include participants with a diagnosis of autism, three studies were reporting on a participant who was not the child with autism and 21 were published before 1994). The systematic review also identified fifteen case series, all of which would also have been excluded for reasons other than sample size (one had a focus outside of the school setting, five did not have a measure of, or focus upon, anxiety, three studies did not include participants with a diagnosis of autism and six were not data based studies). Therefore, the a priori decision to exclude case studies and series did not impact upon the studies meeting inclusion criteria for this review.

\section{Assessment of study quality}

The studies were assessed to ensure they met a minimum quality standard using the Strengthening the Reporting of Observational Studies in Epidemiology (STROBE) checklist (von Elm et al., 2007) available at http://www.strobe$\underline{\text { statement.org/fileadmin/Strobe/uploads/checklists/STROBE_checklist }}$ _v4_cross-sectional.pdf). A global quality score was calculated for each article, giving 1 point for each STROBE item the article addressed. As per Fortin, Stewart, Poitras, Almirall \& Maddocks (2012), articles had to have a quality score of at least 12 out of a possible 22 to be retained in the review. This cut-off was used as it indicates that more than half of the STROBE quality markers were reported in the manuscript. None of the studies identified achieved a score below this cut-off.

\section{Results}

\section{Included papers}


Overall, 32 papers were included in the review. The included papers are summarised in Table 2. Of the 32 papers, $12(37.5 \%)$ were from the same research group (Gadow, DeVincent, Pomeroy \& Azizian, 2005; Gadow, DeVincent \& Schneider, 2008; Gadow, Roohi, DeVincent, Kirsch \& Hatchwell, 2008; Gadow, DeVincent \& Schneider, 2009; Gadow, Roohi, DeVincent, Kirsch \& Hatchwell, 2009; Gadow, Roohi, DeVincent, Kirsch \& Hatchwell, 2010; Gadow, Perlam, Ramdhany \& de Ruiter, 2016; Guttman-Steinmetz et al., 2010; Kaat, Gadow \& Lerner, 2013; Lerner, De Los Reyes, Drabick, Gerber \& Gadow, 2017; Roohi, DeVincent, Hatchwell \& Gadow, 2009; Weisbrot, Gadow, Vincent \& Pomeroy, 2005) with participants recruited through one university hospital developmental disabilities speciality clinic and assessed with similar standardised questionnaires. It is unknown to what extent the samples reported in these articles overlap, if at all. Therefore, where statistics described in this paper contain a large proportion of studies from the same research group, this will be highlighted.

++Insert Table 2 about here++

\section{Research team and study design}

The research was conducted in seven countries, with the majority being conducted in the United States (62.5\%; more than half of which were from the same research group), Singapore (12.5\%), and the United Kingdom (9.4\%). The most common disciplines of the lead author were psychiatry (42.4\%) and psychology (33.3\%), with only four (12.5\%) studies describing school anxiety in children with autism being led by researchers within education departments.

The majority ( $81.2 \%)$ of studies were observational studies, with the remaining six being intervention studies. Three of the intervention studies were school-based cognitive behavioural therapy (Clarke, Hill \& Charman, 2017; Drmic, Aljunied \& Reaven, 2017; 
Luxford, Hadwin \& Kovshoff, 2017), one was cognitive-behavioural therapy with some school-based sessions (Fujii et al., 2013), one was a clinic-based cognitive behavioural therapy study (Ooi et al., 2014), and one explored an intervention to reduce listening-related stress and anxiety in the classroom (Rance, Chisari, Saunders \& Rault, 2017).

All studies reported a quantitative component. The most frequent method of collecting anxiety data was through surveys $(96.9 \%)$. Three studies used interviews and two of them reported the qualitative data in addition to questionnaires; Clarke et al. (2017) used interviews after the intervention to explore emotions and behaviours with parents and children on the autism spectrum; and Drmic et al. (2017) used a semi-structured interview to obtain feedback on the intervention. Fujii et al. (2013) used a standalone standardised diagnostic interview assessment to report categorical data on diagnostic status in relation to anxiety, pre- and post-intervention. No studies used qualitative approaches to explore or describe anxiety symptomatology in children with autism in school settings.

\section{Samples}

Sample sizes ranged from 14 to 301 for descriptive and from 6 to 89 for intervention studies. The sample sizes were largest for the population-based study ( $\mathrm{n}=277$, Chandler et al., 2016) and many of the clinic studies (e.g., $\mathrm{n}=221$ Gadow et al., 2016; $\mathrm{n}=115$ Kaat et al,, 2013). Studies recruiting through schools tended to have sample sizes of 60 or fewer. The most common method of recruitment was via psychiatric clinic $(56.2 \%$; of which $37.5 \%$ was the same psychiatric clinic). Eight (25\%) studies, half of which were intervention studies, recruited at least some of their participants directly through schools.

The average percentage of males across all of the included studies was $86.5 \%$, which is an approximate ratio of 6:1 males:females. The samples were all male in five of the included studies (Clarke et al., 2017; Guttman-Steinmetz et al., 2010; Matsushima et al., 2008, Rance et al., 2017; Roohi et al., 2009), and five studies (Fujii et al., 2013; Hurtig et al., 
2009; Ooi et al, 2014; Pearson et al., 2012; Poon, 2012) reported a ratio reflective of the current reported ratio of males:females in autism (3:1; see Loomes, Hull \& Mandy, 2017). Of the 29 studies that reported the participant age range, six (20.7\%) focussed upon primaryschool-aged children, six (20.7\%) upon secondary-school-aged children, and 17 (58.6\%) reported on children who were in both secondary and primary schools. The majority of studies included children from both mainstream and special educational settings. Three (9.1\%) studies focussing solely upon children in special educational settings and five $(18.2 \%)$ solely recruited children in mainstream settings.

Studies used a range of methods to confirm autism diagnoses. The most common method used to confirm diagnosis was multi-practitioner assessment which was used in $37.5 \%$ of studies (however it must be acknowledged that this was the method used in eleven out of the twelve studies from Gadow's research team). Eight studies (25\%) used the ADOS and/or ADI-R. Fifteen studies provided the proportion of autism diagnostic subtypes for the participants (eight of which were from the same clinic, so there is potential for participant overlap). Within these 15 studies, the average proportion of children with Autistic Disorder was 44.1\%, with Asperger's 32.7\%, and with PDD-NOS 29.6\%. Two studies reported a diagnosis of "High Functioning ASD".

There was variability across papers in reporting additional or comorbid diagnoses in the samples. Thirteen studies $(40.6 \%)$ reported on specific additional diagnoses within the sample, with nine of these stating the level of intellectual disability in the sample and two stating that there were no additional diagnoses. Only three $(9.4 \%)$ studies, all of which were intervention studies (Fujii et al., 2013; Luxford et al., 2017; Ooi et al., 2008), provided details on whether any children in the samples had anxiety diagnoses. From the 32 included studies, $15(45.4 \%)$ reported prescription medication use, ten of which were from the same research team. However, little detail was given as to the types of medication. Two (Fujii et al., 2013; 
Luxford et al., 2017) of the six intervention studies reported on medication use in their sample.

\section{Respondents}

Twenty-nine (90.6\%) of the 32 studies reported parent data and eight $(25 \%)$ included a self-report measure of anxiety for the child with autism. Unsurprisingly, given that this review focuses upon anxiety in the school context, 30 studies $(93.8 \%)$ reported on an anxiety measure completed by teachers. The two studies that did not report upon teacher data were intervention studies, one of which was based at school (Clarke et al., 2017) and one of which integrated sessions at school and collaborated with school providers (Fujii et al., 2013). Clarke et al. (2017) note that they decided not to include teacher ratings of anxiety in their study due to the inconsistencies between schools as to which teacher could fill in the questionnaire in a secondary school environment.

Twenty-seven (84.4\%) studies reported on anxiety measures from multiple informants; 20 studies (62.5\%, of which 12 were from the same research clinic) reported data from parents and teachers. None of the studies reported data from anxiety measures from teachers and children (without parents). Seven studies reported on anxiety measures completed by parents, teachers, and children, although in two of these studies the measures used were not comparable between informants (e.g., in Drmic et al. [2017] parent and teachers completed the DBC but the child completed the SCARED, and in Luxford et al. [2017] parents and children completed the Spence Child Anxiety Scales and the teacher and child completed the Social Worries Questionnaire).

\section{Methods of collecting child anxiety data from teachers}

Eight different measures were used to document teacher-reported anxiety within the school setting. All but one of the studies (97\%) used an anxiety subscale within a broader measure of emotional/behavioural characteristics. Measures used were the Achenbach 
System of Empirically Based Assessment (ASEBA; Achenbach, 2009), Behaviour Assessment System for Children (BASC; Reynolds \& Kamphaus, 1992), Child Symptom Inventory (CSI; Gadow \& Sprafkin, 2002), Child and Adolescent Symptom Inventory (CASI; Gadow \& Sprafkin, 2005), Conners Comprehensive Behaviour Rating Scales (CCBRS, Conners, 2008); Developmental Behaviour Checklist (DBC; Einfeld \& Tonge, 2002) and the Adolescent Symptom Inventory-Fourth Edition (ASI; Gadow \& Sprafkin, 1998). Only one study (Luxford et al., 2017) used an anxiety-specific measure - the School Anxiety Scale (SAS-TR; Lyneham et al., 2008), although the reliability and validity of this measure has not yet been fully explored within children with autism.

All papers except two (Guttmann-Steinmetz et al., 2010; Weisbrot et al., 2005) reported subscale mean scores or diagnostic status and did not provide detail on the profile of items that contributed to those scores. The 15 papers using the ASEBA, BASC, Conners, and DBC only reported overall "anxiety" subscale scores (including the anxious/depressed subscale in the ASEBA and the anxious/shy subscale of the CCBRS). The teacher questionnaires of the CSI, CASI, and ASI have generalised anxiety, social phobia, OCD, and specific phobia subscales, although reporting of subscales varied across the 13 studies that used these measures.

Two papers reported item-level data. Guttmann-Steinmetz et al. (2010) compared ratings from mothers and teachers for children with autism and Attention Deficit Hyperactivity Disorder (ADHD) $(\mathrm{N}=74)$ to children with autism $(\mathrm{N}=130)$ and non-clinical controls $(\mathrm{N}=170)$. Teacher ratings on the five generalised anxiety items were higher for the children with autism and ADHD and autism compared to controls. For three items (acts restless, irritable, tense), children with autism and ADHD scored significantly higher than those with autism alone. For three items (difficulty controlling worries, acts restless, and tense), the mean scores for both the autism and autism with ADHD groups were between 1 
and 2, suggesting that teachers identified these symptoms between sometimes (score of 1) and often (score of 2). In contrast, the mean scores for the controls ranged from $0.25-0.31$ for these three items. The second paper to describe item-level data (Weisbrot et al., 2005) contrasted teacher ratings for children with a PDD diagnosis $(n=268)$ and those without $(n=167)$. They noted that children with PDD scored significantly higher on all items, with the mean scores for children with PDD on items in the social phobia subscale (avoids contact with strangers, excessively shy with peers, and withdraws or freezes in uncomfortable situations) being approximately twice that reported for the controls. When comparing scores for children with Asperger's ( $\mathrm{n}=71)$, autistic disorder ( $\mathrm{n}=85)$, and PDD-NOS $(\mathrm{n}=105)$, they noted significantly higher scores in children with Asperger's than children with autistic disorder on four items (overly concerned about abilities, difficulty controlling worries, tense or unable to relax and "distressing thoughts).

\section{Method of describing and analysing child anxiety data from teachers}

Four studies (Ashburner, Ziviani, \& Rodger, 2010; Hass, Brown, Brady \& Johnson, 2012; Poon, 2012; Rance et al., 2017) only reported teacher data. Three of these studies compared teacher ratings for autism with either typically developing children or children with multiple disabilities. Ashburner et al. (2010) reported significantly higher scores for children with autism on the CCBRS anxious/shy subscale $(\mathrm{p}<.001)$ and the ASRBA-TRF anxiousdepressed subscale compared to typically developing children. Hass et al. (2012) reported that the mean anxiety scores were larger for both the child and adolescent autism sample than typically developing controls, with the mean score for the children with autism (but not adolescents) falling within the clinically significant range. Poon (2012) reports significantly higher scores on the DBC-T anxiety subscale in children with autism than in those with multiple disabilities $(\mathrm{p}<.001)$. The other study (Rance et al., 2017) reported teacher scores prepost intervention. 
Fifteen studies report both parent and teacher data, but do so independently of each other. Two of these were intervention studies focusing upon reducing anxiety; Drmic et al. (2017) who reported reductions post-intervention on the parent but not the teacher measure and Ooi et al. (2008) who reported no pre-post significant reductions on parent or teacher measures of anxiety. The majority of studies that reported parent and teacher separately had a focus on comparing profiles between subgroups, either comparing children with autism to another diagnostic group (Gadow, DeVincent et al., 2009; Guttmann-Steinmetz et al., 2010; Ooi et al., 2014) mixed clinical controls (Weisbrot et al., 2005) or neurotypical control data (Hammond \& Hoffman, 2014), or comparing subgroups within autism based upon age (Foley-Nicpon, Doobay \& Assouline, 2010) or autism genetic markers (Roohi et al., 2009; Gadow, Roohi et al, 2008, 2009; Gadow et al., 2010). Two studies (Gadow, DeVincent et al., 2008; Gadow et al., 2016) explored the clinical correlates of psychiatric ratings in autism but only one (Gadow et al., 2016) goes on to discuss the unique and overlapping correlates between parents and teachers in detail in the discussion. Although not explored statistically, all except three (Gadow et al., 2010; Ooi et al., 2008, 2014) of these studies discuss the similarities and/or differences between parents and teacher ratings in the discussion, although to a varying degree.

Eight papers explored parent and teacher ratings for anxiety (some using multiple methods); six used correlations, three used tests of comparison and one compared agreement in clinical cut-offs. The intervention study by Luxford et al. (2017) correlated parent, teacher and self-report measures of anxiety at baseline, with only the significant correlation being between parent and self-report ratings on the SCAS $(r=.49, \mathrm{p}<.001)$. Their pre-post intervention comparisons were conducted separately for each respondent type. Correlations between parent and teacher ratings of anxiety were also conducted by Hurtig et al. (2009; CBCL: $r=.34, p=n s)$, Kanne, Abbacchi and Constantino (2009; CBCL: $r=.14, p=n s)$, McDonald et al. (2016; BASC-2, $\mathrm{r}=.51, \mathrm{p}<.001)$, Pearson et al., (2012; CCBRS: $\mathrm{r}=.07, \mathrm{p}<.005)$ and Ung 
et al. (2017; CBCL: ICC=0.41, p=ns). Three papers (Barnhill et al., 2000; Gadow et al., 2005; Pearson et al., 2012) compared mean scores on the anxiety subscales between parents and teachers, both reporting either no significant differences between informants or only reporting effect sizes (which were below 0.2). One paper (Kaat et al., 2013) used Kappa to report parentteacher agreement on scores above the symptom and impairment clinical cut-offs for subscale level. Agreement for the generalized anxiety disorder subscale of the CASI-4R was $64-68 \%$ with kappa scores of 0.05-0.14 (considered "poor").

\section{Teacher, parent, and child scores on measures of anxiety}

Table 3 summarises the 19 studies where data were collected and mean scores reported on comparable measures of anxiety across multiple respondents, for example, where both the ASEBA parent and teacher forms were used. Twelve of these studies had the same number of respondents in each respondent group (e.g., 14 parents, 14 teachers, and 14 self-report) and of these, eight had equal numbers of parents and teachers. The remaining seven studies had a different number of respondents in each respondent group, for example, 277 parents and 228 teachers in Chandler et al. (2016), and 46 parents and 23 teachers in Hurtig et al. (2009), which has important implications when comparing similarities or differences between teacher and parent ratings of anxiety.

++Insert Table 3 about here++

Table 3 summarises the mean (and standard deviation) of the teacher and parent scores on corresponding measures. Fifteen studies reported on comparable parent and teacher measures, although only eight of these had an equal number of parent and teacher respondents. On average, across all subscales reported in the 15 studies with parent and teacher data, teacher scores were within $10.2 \%$ of the parent scores. If this is restricted to the studies with equal numbers of parents and teachers, teacher scores were, on average, within 
$12.8 \%$ of parent scores. Studies varied as to whether the teacher or parent reported higher scores (representing more symptoms of anxiety).

A mixed profile of scores is noted across the four studies that report on comparable child, parent, and teacher data. Barnhill et al. (2000) reported data from an equal number $(n=20)$ of children, parents, and teachers on the BASC, noting relatively equal scores between parents and teachers (59.6 and 60.1 respectively) and lower scores on the self-report completed by the child with autism (47.2). A similar pattern was noted by Hammond and Hoffman (2014) using the ASI, but a contrasting pattern (with the highest score being reported by the individual with autism) was reported by Hurtig et al. (2009). Foley Nicpon et al. (2010) reported relatively equal scores across parents $(56.4, \mathrm{n}=52)$, teachers $(56, \mathrm{n}=55)$, and children with autism $(56, \mathrm{n}=45)$.

\section{Discussion}

The purpose of this review was to identify and review the research that has focussed upon anxiety in children with autism within the school setting. The findings indicate that, while there is a growing research base on anxiety in children with autism, that the research relating to anxiety in autism within an academic setting remains very limited, with only 32 published studies meeting inclusion criteria (12 of which were conducted by the same research group). This lack of research is concerning given the combination of the elevated prevalence of anxiety in autism and the levels of academic underachievement reported in students on the spectrum.

Despite the limited number of studies, several important findings emerged through conducting this review. Firstly, that the research to date has documented teacher-reported levels of anxiety in children with autism through mean scores on a range of measures, with the consistent finding that teachers report higher mean scores on anxiety subscales for children with autism than children without autism. However, the research has not yet 
described the phenomenology of the symptomatology within the classroom setting. It cannot be assumed that the symptomatology will present the same as that in children without autism (e.g. see Kerns et al., 2015) nor that it will be the same as that seen in by children with autism within the home setting given the difference in both cognitive and social demands of home and school settings (Allen \& Lerman, 2018) and the recent work suggesting that parents of children with autism report different anxiety symptomatology between home and community settings (Adams, Young et al., 2018). There is therefore a critical need for such work to be undertaken in this area to allow educators to identify the presence anxiety in children with autism, assess its impact on learning and decide whether to implement appropriate educational support strategies and/or refer on for intervention.

Secondly, that the use of teacher data across the studies has not provided a consistent outcome in terms of agreement or differences from parent reported levels of anxiety. Of the six papers that correlated parent and teacher data, half reported a positive correlation and half reported no correlation. Of the three that used a test of difference, none reported any significant difference between parent and teacher scores but the one study exploring agreement between clinical cut-offs reports "poor" agreement. Changes in parent and teacher scores from pre- to post-intervention were also inconsistent, with one study reporting no changes in either informant and one study reporting changes in parent scores but not teacher scores. Together these results highlight the possible complex association between parent and teacher rated anxiety, and further strengthens the case for collecting data from multiple informants, especially for intervention studies, as it cannot be assumed that ratings of anxiety will be similar across different contexts or settings.

Finally, despite aiming to conduct research relating to anxiety, researchers have tended to report on scores collected on anxiety subscales of broad emotional and/or behavioural measures, some of the which have combined anxiety with depression (CBCL) or 
shyness (CCBRS). Of the thirty included studies that gathered information from teachers on student anxiety, only one study (Luxford et al., 2017) used an anxiety-specific questionnaire for teachers, the School Anxiety Scale (SAS-TR, Lyneham et al., 2008). This measure has had limited assessment of its validity in typically developing children and has only been used in one other study of children with autism (which did not formally assess its validity; Adams, Simpson et al., 2018). Differentiating anxiety symptoms from autism characteristics can be challenging and, as a result, there are concerns that relying on measures standardised on typically developing children may not accurately represent the way anxiety manifests in children with autism (Ozsivadjian, Knott \& Magiati, 2012) due to possible typical and atypical signs of anxiety in children with autism (Kerns et al., 2015). An international working group of autism experts has identified the issue of anxiety measurement (including validation of existing measures to address the overlap between autism and anxiety symptoms and the further development of objective measures of anxiety) as a top research priority (Vasa et al., 2018). Such measures (e.g. the Anxiety Scale for Children with Autism Spectrum Disorder; Rodgers et al., 2016) is showing good reliability and validity in schoolaged children with autism (e.g. den Houting, Adams, Roberts \& Keen, 2018a,b) The findings of this review support the conclusions of the working group, highlighting a clear need for either further validation of the SAS-TR for children with autism, or the development of an autism-specific measure of anxiety in the academic setting which aims to capture the full range of anxiety presentations seen in autism.

\section{Methodological issues of available research}

There were a number of methodological issues across a number of the studies identified which should be carefully considered when future research into anxiety and autism in the school setting is planned. Few studies reported on equal sample sizes between teacher and parent questionnaires, limiting the extent to which the scores (e.g. in Table 3) can be 
truly compared, as the samples are not "like for like". There was notable variability in the depth of the cohort descriptions and in the representativeness of the cohort to the broader autism population. Given the included studies were reporting on anxiety (even as part of a broader emotional or behavioural profile), it was surprising that only 15 included data on medication and 11 on additional diagnoses (including those reporting on the presence of intellectual disability). It was also surprising that the educational setting (mainstream or special school) was not described, given that the studies had collected data from teachers and/or that the interventions had taken place within the school setting. There are differences in anxiety levels for children with autism with and without an intellectual disability (van Steensel \& Heeman, 2017), so combining populations from these settings may mean that specific patterns are being missed. Females and children attending special schools were generally underrepresented in the available literature as were participants recruited outside of psychiatric clinics. Future studies should provide more comprehensive descriptions of such important factors when describing their samples and consider the profile of participants compared to the broader autism population in schools.

\section{Barriers to autism and anxiety research in academic settings}

There may be many possible reasons for the lack of research in this area. The absence of anxiety measures that can be completed by teachers, who are arguably the best placed to observe and report on external indicators of anxiety in their students, may mean that researchers are not able to report on specific symptomatology in the school setting. Another possible reason is the barriers that can be encountered when undertaking research in schools (Kasari \& Smith, 2013). For example, Clarke et al. (2017) noted that they intended to gain teacher anxiety ratings for participants but decided against this due to difficulties finding consistency between schools in terms of which teachers would complete the questionnaires. Other studies (e.g. Adams, Simpson et al., 2018) report teacher-questionnaire completion 
rates of less than $50 \%$, even with a full-time project manager focusing upon school liaison. To further our understanding of anxiety at school and to develop effective interventions, it will require researchers to address some of these challenges.

\section{Areas for further research}

Further research is needed that incorporates well-validated anxiety-specific measures that can be completed by multiple informants and are suitable for use with children on the autism spectrum. Due to the possibility of differing presentations and the increased reliance on proxy-report (Adams \& Oliver, 2011) there is also a recognised need to develop specific measures of anxiety (alongside other aspects of mental health) in individuals with co-morbid intellectual disabilities (see reviews by Flynn et al., 2017). In addition, future work needs to go beyond reporting total and subscale scores if our understanding of anxiety in autism is to be enriched, using qualitative approaches and/or item-level analyses to provide rich information about the variability in anxiety presentation in autism across home and school settings (Magiati, Ozsivadijan, \& Kerns, 2017).

Future reviews may wish to include search terms for specific disorders including "social phobia" and "obsessive compulsive disorder" or specific treatments (e.g. "exposure therapy") to explore the extant research on specific disorders and treatments within the school setting. The exclusion of studies based upon single case designs may have impacted upon the literature reviewed, for example it may be that there are studies within the Applied Behavioural Analysis literature that observe behaviours indicative of anxiety (e.g. "fearful behaviour") or describe the functional assessment and analysis of anxiety. Future reviews may wish to amend the inclusion and exclusion criteria to allow such studies to be included and reviewed.

\section{Conclusions}


There is limited research describing anxiety in autism in the school context and the research that is available tends to report on non-anxiety-specific measures and to report a numerical score rather than any detail on presentation or symptomatology. More research must be conducted into the way that anxiety in children with autism presents at school and what, if any, impact it has on their academic engagement and achievement. Further development of teacher- and self-report methods is also an important focus for future research with work to establish the methodological quality of such measures.

\section{Compliance with Ethical Standards:}

This review was supported by an Educational Horizons Grant from the Queensland Department of Education and Training. The funder had no role in the study design, collection, analysis or interpretation of the data, writing the manuscript, or the decision to submit the paper for publication.

Ethical approval: This article does not contain any studies with human participants performed by any of the authors.

\section{References}

Achenbach, T. M. (2009). The Achenbach System of Empirically Based Assessement (ASEBA): Development, Findings, Theory, and Applications. Burlington: University of Vermont Research Center for Children, Youth and Families.

Achenbach, T. M., McConaughy, S. H., \& Howell, C. T. (1987). Child/adolescent behavioral and emotional problems: implications of cross-informant correlations for situational specificity. Psychol Bull, 101, 213-232. 
Adams D., \& Oliver, C. (2011). The expression and assessment of emotions and internal states in individuals with severe or profound intellectual disabilities. Clinical Psychology Review, 31, 293-306. Doi: 10.1016/j.cpr.2011.01.003

Adams, D., Young, K., Simpson, K., \& Keen, D. (2018). Parent descriptions of the presentation and management of anxiousness in children on the autism spectrum. Autism, ePub ahead of print. Doi: 10.1177/1362361318794031.

Adams, D., Simpson, K. \& Keen, D. (2018). School-related anxiety symptomatology in a community sample of primary-school aged on the autism spectrum. Journal of School Psychology, 70, 64-73. Doi: 10.1016/j.jsp.2018.07.003.

Allen J.L. \& Lerman R. (2018). Teacher Responses to Anxiety in Children Questionnaire (TRAC): psychometric properties and relationship with teaching staff characteristics, Emotional and Behavioural Difficulties, 23, 154-168. Doi:

$10.1080 / 13632752.2017 .1376974$

Arbeau, K. A., Coplan, R. J., \& Weeks, M. (2010). Shyness, teacher-child relationships, and socioemotional adjustment in grade 1. International Journal of Behavioral Development, 34, 259269. doi:10.1177/0165025409350959

Ashburner, J., Ziviani, J., \& Rodger, S. (2010). Surviving in the mainstream: Capacity of children with autism spectrum disorders to perform academically and regulate their emotions and behavior at school. Research in Autism Spectrum Disorders, 4, 18-27. doi:10.1016/j.rasd.2009.07.002

Barnhill, G. P., Hagiwara, T., Myles, B. S., Simpson, R. L., Brick, M. L., \& Griswold, D. E. (2000). Parent, teacher, and self-report of problem and adaptive behaviors in children and adolescents with Asperger Syndrome. Diagnostique, 25, 147-167. doi:10.1177/073724770002500205 
Cassidy, S. A., Bradley, L., Bowen, E., Wigham, S., \& Rodgers, J. (2018). Measurement properties of tools used to assess depression in adults with and without autism spectrum conditions: A systematic review. Autism Res., 11, 738-754. doi:10.1002/aur.1922

Chandler, S., Howlin, P., Simonoff, E., O'Sullivan, T., Tseng, E., Kennedy, J., . . Baird, G. (2016). Emotional and behavioural problems in young children with autism spectrum disorder. Developmental Medicine and Child Neurology, 58, 202-208. doi:10.1111/dmcn.12830

Clarke, C., Hill, V., \& Charman, T. (2017). School based cognitive behavioural therapy targeting anxiety in children with autistic spectrum disorder: A quasi-experimental randomised controlled trail incorporating a mixed methods approach. Journal of Autism and Developmental Disorders, 47, 3883-3895. doi:10.1007/s10803-016-2801-x

Conners, C. K. (2008). Conners Comprehensive Behaviour Rating Scales 3rd Edition Manual. Ontario, Canada: Multi-Health Systems.

De Los Reyes, A., Augenstein, T. M., Wang, M., Thomas, S. A., Drabick, D. A., Burgers, D. E., \& Rabinowitz, J. (2015). The validity of the multi-informant approach to assessing child and adolescent mental health. Psychol Bull, 141, 858-900. doi:10.1037/a0038498

den Houting, J., Adams, D., Roberts, J. \& Keen, D (2018a). An exploration of autism-specific and non-autism-specific measures of anxiety symptomatology in school-aged autistic children. Submitted and withdrawn from Autism, Clinical Psychologist, ePub ahead of print. doi: $10.1111 /$ cp.12174.

den Houting, J., Adams, D., Roberts, J. \& Keen, D (2018b). Exploring anxiety symptomatology in school-aged autistic children using an autism-specific assessment. Research in Autism Spectrum Disorders, 50, 73-82. Doi: 10.1016/j.rasd.2018.03.005.

Drmic, I. E., Aljunied, M., \& Reaven, J. (2017). Feasibility, acceptability and preliminary treatment outcomes in a school-based cbt intervention program for adolescents with asd and anxiety in 
singapore. Journal Of Autism And Developmental Disorders, 47, 3909-3929. doi:10.1007/s10803-016-3007-y

Einfeld, S., \& Tonge, B. J. (2002). Developmental Behaviour Checklist. Sydney: University of New South Wales and Monash University.

Flynn, S., Vereenooghe, L., Hastings, R., Adams, D., Cooper, S-A., Gore, N., Hatton, C., Hood, K., Jahoda, A., Langdon, P., McNamara, R., Oliver, C., Roy, A., Totsika, V \& Waite, J. (2017). Measurement tools for mental health problems and mental well-being in people with severe or profound intellectual disabilities: A systematic review. Clinical Psychology Review, 57, 32-44. doi: 10.1016/j.cpr.2017.08.006

Foley Nicpon, M., Doobay, A. F., \& Assouline, S. G. (2010). Parent, Teacher, and Self Perceptions of Psychosocial Functioning in Intellectually Gifted Children and Adolescents with Autism Spectrum Disorder. Journal Of Autism And Developmental Disorders, 40, 1028-1038. doi:10.1007/s10803-010-0952-8

Fortin, M., Stewart, M., Poitras, M. E., Almirall, J., \& Maddocks, H. (2012). A systematic review of prevalence studies on multimorbidity: toward a more uniform methodology. Ann Fam Med, 10, 142-151. doi:10.1370/afm.1337

Fujii, C., Renno, P., McLeod, B. D., Lin, C. E., Decker, K., Zielinski, K., \& Wood, J. J. (2013). Intensive Cognitive Behavioral Therapy for Anxiety Disorders in School-aged Children with Autism: A Preliminary Comparison with Treatment-as-Usual. School Mental Health, 5, 2537. doi:10.1007/s12310-012-9090-0

Gadow, K. D., DeVincent, C., \& Schneider, J. (2008). Predictors of Psychiatric Symptoms in Children with an Autism Spectrum Disorder. Journal Of Autism And Developmental Disorders, 38, 1710-1720. doi:10.1007/s10803-008-0556-8

Gadow, K. D., Devincent, C. J., Pomeroy, J., \& Azizian, A. (2005). Comparison of DSM-IV Symptoms in Elementary School-Age Children with PDD versus Clinic and Community 
Samples. Autism: The International Journal of Research and Practice, 9, 392-415. doi:0.1177/1362361305056079

Gadow, K. D., DeVincent, C. J., \& Schneider, J. (2009). Comparative Study of Children with ADHD Only, Autism Spectrum Disorder + ADHD, and Chronic Multiple Tic Disorder + ADHD. Journal of Attention Disorders, 12, 474-485. doi:10.1177/1087054708320404

Gadow, K. D., Perlman, G., Ramdhany, L., \& de Ruiter, J. (2016). Clinical Correlates of Cooccurring Psychiatric and Autism Spectrum Disorder (ASD) Symptom-Induced Impairment in Children with ASD. Journal of Abnormal Child Psychology, 44, 129-139. doi:10.1007/s10802-015-9979-9

Gadow, K. D., Roohi, J., DeVincent, C. J., \& Hatchwell, E. (2008). Association of ADHD, Tics, and Anxiety with Dopamine Transporter ("DAT1") Genotype in Autism Spectrum Disorder. Journal of Child Psychology and Psychiatry, 49, 1331-1338. doi:10.1111/j.14697610.2008.01952.x

Gadow, K. D., Roohi, J., Devincent, C. J., Kirsch, S., \& Hatchwell, E. (2009). Association of COMT (Val158Met) and BDNF (Val66Met) Gene Polymorphisms with Anxiety, ADHD and Tics in Children with Autism Spectrum Disorder. Journal Of Autism And Developmental Disorders, 39, 1542-1551. doi:10.1007/s10803-009-0794-4

Gadow, K. D., Roohi, J., DeVincent, C. J., Kirsch, S., \& Hatchwell, E. (2010). Glutamate transporter gene (SLC1A1) single nucleotide polymorphism (rs301430) and repetitive behaviors and anxiety in children with autism spectrum disorder. Journal Of Autism And Developmental Disorders, 40, 1139-1145. doi:10.1007/s10803-010-0961-7

Gadow, K. D., \& Sprafkin, J. (1998). Adolescent Symptom Inventory-4 norms manual. Stony Brook, NY: Checkmate Plus.

Gadow, K. D., \& Sprafkin, J. (2002). Child Symptom Inventory-4 screening and norms manual. Stony Brook, NY: Checkmate Plus. 
Gadow, K. D., \& Sprafkin, J. (2005). Child and adolescent symptom inventory-4R. Stony Brook, NY: Checkmate Plus.

Guttmann-Steinmetz, S., Gadow, K. D., DeVincent, C. J., \& Crowell, J. (2010). Anxiety Symptoms in Boys with Autism Spectrum Disorder, Attention-Deficit Hyperactivity Disorder, or Chronic Multiple Tic Disorder and Community Controls. Journal Of Autism And Developmental Disorders, 40, 1006-1016. doi:10.1007/s10803-010-0950-х

Hammond, R. K., \& Hoffman, J. M. (2014). Adolescents with High-Functioning Autism: An Investigation of Comorbid Anxiety and Depression. Journal of Mental Health Research in Intellectual Disabilities, 7, 246-263. doi:10.1080/19315864.2013.843223

Hass, M. R., Brown, R. S., Brady, J., \& Johnson, D. B. (2012). Validating the BASC-TRS for Use with Children and Adolescents with an Educational Diagnosis of Autism. Remedial and Special Education, 33, 173-183. doi:10.1177/0741932510383160

Hurtig, T., Kuusikko, S., Mattila, M.-L., Haapsamo, H., Ebeling, H., Jussila, K., . . Moilanen, I. (2009). Multi-Informant Reports of Psychiatric Symptoms among High-Functioning Adolescents with Asperger Syndrome or Autism. Autism: The International Journal of Research and Practice, 13, 583-598.

Kaat, A. J., Gadow, K. D., \& Lecavalier, L. (2013). Psychiatric Symptom Impairment in Children with Autism Spectrum Disorders. Journal of Abnormal Child Psychology, 41, 959-969. doi:10.1007/s10802-013-9739-7

Kanne, S. M., Abbacchi, A. M., \& Constantino, J. N. (2009). Multi-Informant Ratings of Psychiatric Symptom Severity in Children with Autism Spectrum Disorders: The Importance of Environmental Context. Journal Of Autism And Developmental Disorders, 39, 856-864. doi:10.1007/s10803-009-0694-7

Kanner, L. (1943). Autistic disturbances of affective contact. Nervous Child, 2, 217-250. 
Kasari, C., \& Smith, T. (2013). Interventions in schools for children with autism spectrum disorder: methods and recommendations. Autism, 17, 254-267. doi:10.1177/1362361312470496

Keen, D., Adams, D., Simpson, K., den Houting, J., \& Roberts, J. (2017). Anxiety-related symptomatology in young children on the autism spectrum. Autism, 1362361317734692. doi:10.1177/1362361317734692

Keen, D., Webster, A., \& Ridley, G. (2016). How well are children with autism spectrum disorder doing academically at school? An overview of the literature. Autism, 20, 276-294. doi:10.1177/1362361315580962

Kerns, C. M., Maddox, B. B., Kendall, P. C., Rump, K., Berry, L., Schultz, R. T., . . Miller, J. (2015). Brief measures of anxiety in non-treatment-seeking youth with autism spectrum disorder. Autism, 19, 969-979. doi:10.1177/1362361314558465

Lerner, M. D., De Los Reyes, A., Drabick, D. A., Gerber, A. H., \& Gadow, K. D. (2017). Informant discrepancy defines discrete, clinically useful autism spectrum disorder subgroups. Journal of Child Psychology and Psychiatry, 58, 829-839. doi:10.1111/jcpp.12730

Loomes, R., Hull, L., \& Mandy, W. P. L. (2017). What Is the Male-to-Female Ratio in Autism Spectrum Disorder? A Systematic Review and Meta-Analysis. J Am Acad Child Adolesc Psychiatry, 56, 466-474. doi:10.1016/j.jaac.2017.03.013

Luxford, S., Hadwin, J. A., \& Kovshoff, H. (2017). Evaluating the effectiveness of a school-based cognitive behavioural therapy intervention for anxiety in adolescents diagnosed with autism spectrum disorder. Journal Of Autism And Developmental Disorders, 47, 3896-3908. doi: $10.1007 / \mathrm{s} 10803-016-2857-7$

Lyneham, H. J., Street, A. K., Abbott, M. J., \& Rapee, R. M. (2008). Psychometric properties of the School Anxiety Scale-Teacher Report (SAS-TR). J Anxiety Disord, 22, 292-300. doi:10.1016/j.janxdis.2007.02.001 
Matsushima, N., Miyawaki, D., Tsuji, H., Takahashi, K., Horino, A., Kawaguchi, T., . . Kiriike, N. (2008). Evaluation of attention-deficit/hyperactivity disorder symptoms in male children with high-functioning pervasive developmental disorders. Osaka City Med J, 54, 1-10.

McDonald, C. A., Lopata, C., Donnelly, J. P., Thomeer, M. L., Rodgers, J. D., \& Jordan, A. K. (2016). Informant discrepancies in externalizing and internalizing symptoms and adaptive skills of high-functioning children with autism spectrum disorder. Sch Psychol Q, 31, 467477. doi:10.1037/spq0000150

Murray, L., Cresswell, C., \& Cooper, P. J. (2009). The Development of Anxiety Disorders in Childhood: An Integrative Review. Psychological Medicine, 39, 1413-1423. doi:10.1017/S0033291709005157

Ooi, Y. P., Lam, C. M., Sung, M., Tan, W. T. S., Goh, T. J., Fung, D. S. S., . . Chua, A. (2008). Effects of cognitive-behavioural therapy on anxiety for children with high-functioning autistic spectrum disorders. Singapore Medical Journal, 49, 215-220.

Ooi, Y. P., Rescorla, L., Sung, M., Fung, D. S. S., Woo, B., \& Ang, R. P. (2014). Comparisons between autism spectrum disorders and anxiety disorders: Findings from a clinic sample in Singapore. Asia-Pacific Psychiatry, 6(1), 46-53. doi:10.1111/j.1758-5872.2012.00228.x

Ozsivadjian, A., Knott, F., \& Magiati, I. (2012). Parent and child perspectives on the nature of anxiety in children and young people with autism spectrum disorders: a focus group study. Autism, 16, 107-121. doi:10.1177/1362361311431703

Pearson, D. A., Aman, M. G., Arnold, L., Lane, D. M., Loveland, K. A., Santos, C. W., . . Cleveland, L. A. (2012). High concordance of parent and teacher attentiondeficit/hyperactivity disorder ratings in medicated and unmedicated children with autism spectrum disorders. Journal of Child and Adolescent Psychopharmacology, 22, 284-291. doi:10.1089/cap.2011.0067 
Pettigrew, M., \& Roberts, H. (2005). Systematic Reviews in the Social Sciences: A Practical Guide (Vol. Victoria, Australia): Blackwell.

Polanczyk, G. V., Salum, G. A., Sugaya, L. S., Caye, A., \& Rohde, L. A. (2015). Annual research review: A meta-analysis of the worldwide prevalence of mental disorders in children and adolescents. J Child Psychol Psychiatry, 56, 345-365. doi:10.1111/jcpp.12381

Poon, K. K. (2012). Challenging behaviors among children with autism spectrum disorders and multiple disabilities attending special schools in Singapore. Research In Developmental Disabilities, 33, 578-582. doi:10.1016/j.ridd.2011.10.025

Rance, G., Chisari, D., Saunders, K., \& Rault, J. L. (2017). Reducing Listening-Related Stress in School-Aged Children with Autism Spectrum Disorder. Journal Of Autism And Developmental Disorders, 47, 2010-2022. doi:10.1007/s10803-017-3114-4

Reynolds, C. R., \& Kamphaus, R. W. (1992). BASC: Behavior assessment system for children. Circle Pines, MN: American Guidance Service.

Rodgers J, Wigham S, McConachie H, et al. (2016) Development of the anxiety scale for children with autism spectrum disorder (ASC-ASD). Autism Research, 9,1205-1215. doi: 10.1002/aur.1603

Roohi, J., DeVincent, C. J., Hatchwell, E., \& Gadow, K. D. (2009). Association of a monoamine oxidase: A gene promoter polymorphism with ADHD and anxiety in boys with autism spectrum disorder. Journal Of Autism And Developmental Disorders, 39, 67-74. doi:10.1007/s10803-008-0600-8

Saggers, B., Klug, D., Harper-Hill, K., Costley, D., Clark, T., Bruck, S., . . Carrington, S. (2016). Australian Autism Educational Needs Analysis - What are the needs of schools, parents and students on the autism spectrum? Brisbane: Cooperative Research Centre for Living with Autism. 
Schniering, C. A., Hudson, J. L., \& Rapee, R. M. (2000). Issues in the diagnosis and assessment of anxiety disorders in children and adolescents. Clin Psychol Rev, 20, 453-478.

Simpson, K., Keen, D., Adams, D., Alston-Knox, C., \& Roberts, J. (2018). Participation of children on the autism spectrum in home, school and community. Child: Care, Health and Development, 44, 99-107. Doi: 10.1111/cch.12483

Spain, D., Sin, J., Harwood, L., Mendez, M. A., \& Happe, F. (2017). Cognitive behaviour therapy for social anxiety in autism spectrum disorder: a systematic review. Advances in Autism, 3, 34-46. doi:10.1108/AIA-07-2016-0020

Ung, D., Boone, D. M., McBride, N., Howie, F., Scalli, L., \& Storch, E. A. (2017). Parent and teacher agreement of behavior problems in youth diagnosed with and without Autism Spectrum Disorders. Journal of Child and Family Studies, 26, 370-380. doi:10.1007/s10826016-0566-7

Ung, D., Selles, R., Small, B. J., \& Storch, E. A. (2015). A Systematic Review and Meta-Analysis of Cognitive-Behavioral Therapy for Anxiety in Youth with High-Functioning Autism Spectrum Disorders. Child Psychiatry Hum Dev, 46, 533-547. doi:10.1007/s10578-014-0494$\mathrm{y}$

van Steensel, F. J., Bogels, S. M., \& Perrin, S. (2011). Anxiety disorders in children and adolescents with Autistic spectrum disorders: A meta-analysis. Clinical Child and Family Psychology Review, 14, 302-317. doi:10.1007/s10567-011-0097-0

van Steensel, F. J. A., \& Heeman, E. J. (2017). Anxiety Levels in Children with Autism Spectrum Disorder: A Meta-Analysis. Journal of Child and Family Studies, 26, 1753-1767. doi:10.1007/s10826-017-0687-7

Vasa, R. A., Carroll, L. M., Nozzolillo, A. A., Mahajan, R., Mazurek, M. O., Bennett, A. E., . . . Bernal, M. P. (2014). A systematic review of treatments for anxiety in youth with autism spectrum disorders. J Autism Dev Disord, 44, 3215-3229. doi:10.1007/s10803-014-2184-9 
Vasa, R. A., Keefer, A., Reaven, J., South, M., \& White, S. W. (2018). Priorities for Advancing Research on Youth with Autism Spectrum Disorder and Co-occurring Anxiety. J Autism Dev Disord, 48, 925-934. doi:10.1007/s10803-017-3320-0

von Elm, E., Altman, D. G., Egger, M., Pocock, S. J., Gøtzsche, P. C., \& Vandenbroucke, J. P. (2007). STROBE Initiative. The Strengthening the Reporting of Observational Studies in Epidemiology (STROBE) statement: guidelines for reporting observational studies. Epidemiology, 18, 800-804.

Weisbrot, D. M., Gadow, K. D., DeVincent, C. J., \& Pomeroy, J. (2005). The presentation of anxiety in children with pervasive developmental disorders. Journal of Child and Adolescent Psychopharmacology, 15, 477-496. doi:10.1089/cap.2005.15.477

White, S. W., Mazefsky, C. A., Dichter, G. S., Chiu, P. H., Richey, J. A., \& Ollendick, T. H. (2014). Social-cognitive, physiological, and neural mechanisms underlying emotion regulation impairments: understanding anxiety in autism spectrum disorder. Int J Dev Neurosci, 39, 2236. doi:10.1016/j.ijdevneu.2014.05.012

Wigham, S., \& McConachie, H. (2014). Systematic review of the properties of tools used to measure outcomes in anxiety intervention studies for children with autism spectrum disorders. PLoS One, 9, e85268. doi:10.1371/journal.pone.0085268

Wood, J. J., \& Gadow, K. D. (2010). Exploring the nature and function of anxiety in youth with autism spectrum disorders. Clinical Psychology: Science and Practice, 17, 281-292. doi:10.1111/j.1468-2850.2010.01220.x 
Table 1

Search Strategy

\begin{tabular}{lll}
\hline Autism & Anxiety & School \\
\hline Autis* OR Asperger* OR & anxi* OR psycho* OR & teacher* OR school* OR \\
asd OR pdd OR pervasive & mental health OR emotion* & educat* OR academic OR \\
developmental disorder & OR internali* OR & informant \\
& psychiatric &
\end{tabular}

* Search strings were connected by the Boolean Operator "AND”. 
Table 2

Studies Included in the Review

\begin{tabular}{|c|c|c|c|c|c|c|c|c|c|c|c|}
\hline \multirow{2}{*}{ Study } & \multirow{2}{*}{$\begin{array}{c}\mathrm{N}^{1} \\
\text { with } \\
\text { ASD }\end{array}$} & \multirow{2}{*}{$\begin{array}{c}\text { Age } \\
\text { (mean, sd, } \\
\text { range) }\end{array}$} & \multirow{2}{*}{$\begin{array}{c}\% \\
\text { male }\end{array}$} & \multirow{2}{*}{$\begin{array}{l}\text { Study } \\
\text { design }\end{array}$} & \multirow{2}{*}{$\begin{array}{l}\text { Diagnoses and } \\
\text { verification } \\
\text { (V) }\end{array}$} & \multirow{2}{*}{$\begin{array}{l}\text { Additional } \\
\text { diagnoses, } \\
\text { medication }\end{array}$} & \multirow{2}{*}{$\begin{array}{l}\text { Sampling } \\
\text { technique }\end{array}$} & \multirow{2}{*}{$\begin{array}{l}\text { School (\% } \\
\text { mainstream) }\end{array}$} & \multicolumn{3}{|c|}{ Anxiety measure } \\
\hline & & & & & & & & & Parent & Teacher & Child \\
\hline $\begin{array}{l}\text { Ashburner } \\
\text { et al. (2010) }\end{array}$ & 28 & $\begin{array}{c}-2 \\
6-10\end{array}$ & 86 & $\mathrm{D}$ & $\begin{array}{l}\text { ASD } \\
\text { V: GARS, } \\
\text { GADS }\end{array}$ & $\begin{array}{c}\text { No additional } \\
\text { diag. } \\
-\end{array}$ & - & 100 & - & $\begin{array}{c}\text { Q: } \\
\text { CCBRS } \\
\text { ASEBA- } \\
\text { TRF }\end{array}$ & - \\
\hline $\begin{array}{l}\text { Barnhill et } \\
\text { al. }(2000)\end{array}$ & 20 & $\begin{array}{c}10.7 \\
5-16.8\end{array}$ & 95 & $\mathrm{D}$ & $\begin{array}{c}\text { Asp } \\
\text { V: Prac }\end{array}$ & - & $\begin{array}{l}\text { Previous } \\
\text { study }\end{array}$ & 60 & $\begin{array}{c}\text { Q: } \\
\text { BASC-P }\end{array}$ & $\begin{array}{c}\text { Q: } \\
\text { BASC-T }\end{array}$ & $\begin{array}{c}\text { Q: } \\
\text { BASC-C }\end{array}$ \\
\hline $\begin{array}{l}\text { Chandler et } \\
\text { al. (2016) }\end{array}$ & 277 & $\begin{array}{c}6(1.1) \\
4-8\end{array}$ & 82 & $\mathrm{D}$ & $\begin{array}{c}\text { ASD } \\
\text { V: SCQ }\end{array}$ & - & $\begin{array}{l}\text { Population } \\
\text { study }\end{array}$ & 77 & Q: DBC-P & $\begin{array}{l}\text { Q: DBC- } \\
\text { T }\end{array}$ & - \\
\hline $\begin{array}{c}\text { Clarke et al. } \\
\text { (2017) }\end{array}$ & 28 & $\begin{array}{c}12.8(0.8) \\
11-14\end{array}$ & 100 & I & $\begin{array}{c}\text { ASD } \\
\mathrm{V}: \text { MDA }\end{array}$ & $\begin{array}{l}\text { No additional } \\
\text { diag. }\end{array}$ & Schools & - & $\begin{array}{c}\text { I, Q: } \\
\text { SCAS-P }\end{array}$ & - & $\begin{array}{c}\text { I, Q: } \\
\text { SCAS-C }\end{array}$ \\
\hline $\begin{array}{l}\text { Drmic et al. } \\
\text { (2017) }\end{array}$ & 44 & $13-15$ & 86 & I & $\begin{array}{c}\text { ASD } \\
\text { V: ADOS, } \\
\text { ADI }\end{array}$ & - & Schools & 100 & $\begin{array}{c}\text { I, Q: } \\
\text { SCARED }\end{array}$ & DBC-T & $\begin{array}{c}\text { Q: } \\
\text { SCARED }\end{array}$ \\
\hline $\begin{array}{l}\text { Foley } \\
\text { Nicpon et } \\
\text { al. (2010) }\end{array}$ & 54 & $\begin{array}{c}10.4(3.0) \\
5-17\end{array}$ & 85 & $\mathrm{D}$ & $\begin{array}{c}\text { AD 37\%, } \\
\text { Asp 43\% } \\
\text { PDD-NOS } \\
20 \% \\
\text { V: ADOS, } \\
\text { ADI }\end{array}$ & Gifted 100\% & - & 100 & $\begin{array}{l}\text { Q: BASC- } \\
\text { PRS }\end{array}$ & $\begin{array}{c}\text { Q: } \\
\text { BASC- } \\
\text { TRS }\end{array}$ & $\begin{array}{l}\text { BASC- } \\
\text { SRS }\end{array}$ \\
\hline $\begin{array}{l}\text { Fujii et al. } \\
\text { (2013) }\end{array}$ & 7 & $\begin{array}{c}8.7(1.8) \\
7-11\end{array}$ & 71 & I & $\begin{array}{c}\text { AD } 91 \% \\
\text { PDD-NOS } 9 \% \\
\text { V: ADI, } \\
\text { ADOS }\end{array}$ & $\begin{array}{c}\text { Anxiety } 100 \% \\
\text { ID } 0 \% \\
\text { Med: Psy } \\
29 \%\end{array}$ & Clinic & - & I: ADI-S & - & - \\
\hline
\end{tabular}




\begin{tabular}{|c|c|c|c|c|c|c|c|c|c|c|c|}
\hline $\begin{array}{l}\text { Gadow et } \\
\text { al. (2008a) }\end{array}$ & 238 & $\begin{array}{c}8.6(1.9) \\
6-12\end{array}$ & 86 & $\mathrm{D}$ & $\begin{array}{c}\text { AD 19\% } \\
\text { Asp 38\% } \\
\text { PDD-NOS } \\
43 \% \\
\text { V: Prac-M }\end{array}$ & $\begin{array}{c}\text { ID } 0 \% \\
\text { Med: } 41 \%\end{array}$ & Clinic & 20 & Q: CSI-4 & Q: CSI-4 & - \\
\hline $\begin{array}{l}\text { Gadow et } \\
\text { al. (2005) }\end{array}$ & 301 & $\begin{array}{c}8.3(1.8) \\
6-12\end{array}$ & 85 & $\mathrm{D}$ & $\begin{array}{c}\text { AD 34\%, } \\
\text { Asp 27\% } \\
\text { PDD-NOS } \\
39 \% \\
\text { V: Prac-M }\end{array}$ & Med: 38\% & Clinic & 17 & Q: CSI-5 & Q: CSI-5 & - \\
\hline $\begin{array}{l}\text { Gadow et } \\
\text { al. (2009a) }\end{array}$ & 88 & $\begin{array}{c}8.5(1.9) \\
6-12\end{array}$ & 84 & $\mathrm{D}$ & $\begin{array}{c}\text { ASD } \\
\text { V: Prac-M }\end{array}$ & $\begin{array}{c}\text { ADHD 100\% } \\
\text { Med: } 45 \%\end{array}$ & Clinic & 26 & Q: CSI-4 & Q: CSI-4 & - \\
\hline $\begin{array}{l}\text { Gadow et } \\
\text { al. (2016) }\end{array}$ & 221 & $\begin{array}{c}10.4(3.3) \\
6-18\end{array}$ & 81 & $\mathrm{D}$ & $\begin{array}{c}\text { ASD } \\
\text { V: Prac-M }\end{array}$ & $\begin{array}{c}\text { Med: Psy } \\
39 \%\end{array}$ & Clinic & 26 & $\begin{array}{c}\text { Q: CASI- } \\
4 \mathrm{R}\end{array}$ & $\begin{array}{l}\text { Q: CASI- } \\
4 \mathrm{R}\end{array}$ & - \\
\hline $\begin{array}{l}\text { Gadow et } \\
\text { al. (2008b) }\end{array}$ & 67 & $\begin{array}{c}\text { G1: } 6.8(2.6) \\
4-14\end{array}$ & 87 & $\mathrm{D}$ & $\begin{array}{c}\text { AD 40\% } \\
\text { Asp 23\% } \\
\text { PDD-NOS } \\
37 \% \\
\text { V: Prac-M }\end{array}$ & Med: $24 \%$ & Clinic & 16 & Q: CSI-4 & Q: CSI-4 & - \\
\hline $\begin{array}{l}\text { Gadow et } \\
\text { al. }(2009 b)\end{array}$ & 67 & $\begin{array}{c}\text { G1 } 6.8(2.6) \\
4-14\end{array}$ & 87 & $\mathrm{D}$ & $\begin{array}{c}\text { AD 40\% } \\
\text { Asp 23\% } \\
\text { PDD-NOS } \\
37 \% \\
\text { V: Prac-M }\end{array}$ & Med: $24 \%$ & Clinic & 16 & Q: CSI-5 & Q: CSI-5 & - \\
\hline $\begin{array}{l}\text { Gadow et } \\
\text { al. (2010) }\end{array}$ & 67 & $\begin{array}{c}6.9(2.6) \\
4-14\end{array}$ & 87 & $\mathrm{D}$ & $\begin{array}{c}\text { ASD } \\
\text { V: Prac-M }\end{array}$ & $\begin{array}{c}\text { Med: Psy } \\
24 \%\end{array}$ & Clinic & Check & Q: CSI-4 & Q: CSI-4 & - \\
\hline
\end{tabular}




\begin{tabular}{|c|c|c|c|c|c|c|c|c|c|c|c|}
\hline $\begin{array}{l}\text { Guttmann- } \\
\text { Steinmetz } \\
\text { et al. (2010) }\end{array}$ & 204 & $\begin{array}{c}\text { ASD } 8.7(1.9) \\
\text { ASD+ADHD } \\
8.6(1.9) \\
-\end{array}$ & 100 & $\mathrm{D}$ & $\begin{array}{c}\text { AD 17\% } \\
\text { Asp 38\% } \\
\text { PDD-NOS } \\
45 \% \\
\text { V: Prac-M }\end{array}$ & - & Clinic & 20 & Q: CSI-4 & Q: CSI-4 & - \\
\hline $\begin{array}{l}\text { Hammond } \\
\text { and } \\
\text { Hoffman } \\
\text { (2014) }\end{array}$ & 14 & $\begin{array}{c}13.9(2.2) \\
12-19\end{array}$ & 93 & $\mathrm{D}$ & $\begin{array}{c}\text { Asp 36\% } \\
\text { AD 29\% } \\
\text { PDD-NOS 7\% } \\
\text { DK } 29 \% \\
\text { V: } n=10 \text { Com., } \\
\text { n=4 ASDS }\end{array}$ & - & $\begin{array}{l}\text { Clinic } \\
\text { Schools }\end{array}$ & - & Q: ASI & Q: ASI & Q: YSI \\
\hline $\begin{array}{c}\text { Hass et al. } \\
\text { (2012) }\end{array}$ & 60 & - & 87 & $\mathrm{D}$ & $\begin{array}{c}\text { ASD } \\
\text { V: Ed. }\end{array}$ & ID $0 \%$ & Schools & - & - & $\begin{array}{c}\text { Q: BASC } \\
\text { TRS }\end{array}$ & \\
\hline $\begin{array}{l}\text { Hurtig et al. } \\
\qquad(2009)\end{array}$ & 43 & $\begin{array}{c}13(1.5) \\
11-17\end{array}$ & 74 & $\mathrm{D}$ & $\begin{array}{c}\text { Asp 51\% } \\
\text { HFA 49\% } \\
\text { V: ADOS, } \\
\text { ADI }\end{array}$ & $\begin{array}{c}\text { Receive } \\
\text { psychiatric } \\
\text { treatment } 23 \%\end{array}$ & $\begin{array}{c}\text { Previous } \\
\text { study }\end{array}$ & - & $\begin{array}{c}\text { Q: } \\
\text { ASEBA- } \\
\text { CBCL }\end{array}$ & $\begin{array}{c}\text { Q: } \\
\text { ASEBA- } \\
\text { TRF }\end{array}$ & $\begin{array}{c}\text { Q: } \\
\text { ASEBA- } \\
\text { SR }\end{array}$ \\
\hline $\begin{array}{l}\text { Kaat et al. } \\
(2013)\end{array}$ & 115 & $\begin{array}{c}8.5(1.8) \\
6-12\end{array}$ & 86 & $\mathrm{D}$ & $\begin{array}{c}\text { AD 31\% } \\
\text { Asp 19\% } \\
\text { PDD-NOS } \\
50 \% \\
\text { V: Prac-M }\end{array}$ & $\begin{array}{c}\text { ID } 23 \% \\
\text { Med: } 26 \%\end{array}$ & Clinic & 25 & $\begin{array}{c}\text { Q: CASI- } \\
4 \mathrm{R}\end{array}$ & $\begin{array}{c}\text { Q: CASI- } \\
\text { 4R }\end{array}$ & - \\
\hline $\begin{array}{l}\text { Kanne et al. } \\
\qquad(2009)\end{array}$ & 177 & $\begin{array}{c}7.3(3.9) \\
3-18\end{array}$ & 85 & $\mathrm{D}$ & $\begin{array}{c}\text { Asp } 73 \% \\
\text { AD } 27 \% \\
\text { V: SRS, } \\
\text { ADOS }(87 \%)\end{array}$ & - & Clinic & - & $\begin{array}{c}\text { Q: } \\
\text { ASEBA- } \\
\text { CBCL }\end{array}$ & $\begin{array}{c}\text { Q: } \\
\text { ASEBA- } \\
\text { TRF }\end{array}$ & - \\
\hline $\begin{array}{l}\text { Lerner et al. } \\
\qquad(2017)\end{array}$ & 283 & $\begin{array}{c}10.5(3.3) \\
6-18\end{array}$ & 82 & $\mathrm{D}$ & $\begin{array}{c}\text { ASD } \\
\mathrm{V}: \text { ADOS }\end{array}$ & $\begin{array}{c}\text { Med: Psy } \\
42 \%\end{array}$ & Clinic & 31 & $\begin{array}{c}\text { Q: CASI- } \\
\quad 4 \mathrm{R}\end{array}$ & $\begin{array}{c}\text { Q: CASI- } \\
\quad 4 \mathrm{R}\end{array}$ & - \\
\hline
\end{tabular}




\begin{tabular}{|c|c|c|c|c|c|c|c|c|c|c|c|}
\hline $\begin{array}{l}\text { Luxford et } \\
\text { al. (2017) }\end{array}$ & 35 & $\begin{array}{c}13.2(1.1) \\
11-15\end{array}$ & 89 & I & $\begin{array}{c}\text { ASD } \\
\text { V: Prac, SCQ }\end{array}$ & $\begin{array}{c}\text { High anxiety } \\
100 \% \\
\text { ID } 0 \% \\
\text { Med: } 0 \%\end{array}$ & Schools & 100 & $\begin{array}{c}\text { Q: SCAS- } \\
\text { P }\end{array}$ & $\begin{array}{l}\text { Q: SAS- } \\
\text { TR } \\
\text { Q: SWQ }\end{array}$ & $\begin{array}{c}\text { Q: SCAS- } \\
\text { C } \\
\text { Q: SWQ }\end{array}$ \\
\hline $\begin{array}{l}\text { Matsushima } \\
\text { et al. (2008) }\end{array}$ & 36 & $\begin{array}{c}\text { PDD: } \\
10.9(3.1) \\
\text { PDD+ADHD } \\
9.6(2.4) \\
6-15\end{array}$ & 100 & $\mathrm{D}$ & $\begin{array}{c}\text { AD } 89 \%, \\
\text { PDD-NOS } \\
11 \% \\
\text { V: Prac-M }\end{array}$ & ID $0 \%$ & Clinic & - & $\begin{array}{c}\text { Q: } \\
\text { ASEBA- } \\
\text { CBCL }\end{array}$ & $\begin{array}{c}\text { Q: } \\
\text { ASEBA- } \\
\text { TRF }\end{array}$ & - \\
\hline $\begin{array}{l}\text { McDonald } \\
\text { et al. (2016) }\end{array}$ & 118 & $\begin{array}{c}8.74(1.32) \\
6-11\end{array}$ & 90 & $\mathrm{D}$ & $\begin{array}{c}\text { HFA } \\
\mathrm{V}: \text { ADI }\end{array}$ & $\begin{array}{c}\text { Med: Psy } \\
33 \%\end{array}$ & $\begin{array}{l}\text { Previous } \\
\text { study }\end{array}$ & 18 & Q: BASC & $\begin{array}{c}\text { Q: } \\
\text { BASC- }\end{array}$ & - \\
\hline $\begin{array}{l}\text { Ooi et al. } \\
(2008)\end{array}$ & 6 & $\begin{array}{c}11.5(.8) \\
9-13\end{array}$ & DK & I & $\begin{array}{c}\text { ASD or Asp } \\
\text { V: Prac }\end{array}$ & $\begin{array}{c}\text { Anxiety: } \\
100 \% \\
\text { ID } 0 \%\end{array}$ & Schools & 0 & $\begin{array}{c}\text { Q: SCAS- } \\
\text { P }\end{array}$ & Q: ACAS & $\begin{array}{c}\text { Q: SCAS- } \\
\text { C }\end{array}$ \\
\hline $\begin{array}{l}\text { Ooi et al. } \\
(2014)\end{array}$ & 86 & $\begin{array}{c}9.8(3.6) \\
4-18\end{array}$ & 79 & $\mathrm{D}$ & $\begin{array}{c}\text { ASD } \\
\text { V: Prac }\end{array}$ & $\begin{array}{c}\text { Med: Psy } \\
47 \%\end{array}$ & Clinic & - & $\begin{array}{c}\text { Q: } \\
\text { ASEBA- } \\
\text { CBCL }\end{array}$ & $\begin{array}{c}\text { Q: } \\
\text { ASEBA- } \\
\text { TRF }\end{array}$ & - \\
\hline $\begin{array}{l}\text { Pearson et } \\
\text { al. (2012) }\end{array}$ & 86 & $\begin{array}{c}9.3(1.9) \\
6-13\end{array}$ & 77 & $\mathrm{D}$ & $\begin{array}{c}\text { AD 58\% } \\
\text { PDD-NOS } \\
23 \% \\
\text { Asp 19\% } \\
\text { V: ADI, } \\
\text { ADOS }\end{array}$ & - & $\begin{array}{l}\text { Schools } \\
\text { Parent } \\
\text { group }\end{array}$ & - & $\begin{array}{c}\text { Q: } \\
\text { CCBRS }\end{array}$ & $\begin{array}{c}\text { Q: } \\
\text { CCBRS }\end{array}$ & - \\
\hline $\begin{array}{l}\text { Poon } \\
(2012)\end{array}$ & 322 & $9.5(3.0)$ & 71 & $\mathrm{D}$ & $\begin{array}{c}\text { ASD } \\
\text { V: Prac }\end{array}$ & - & Schools & 0 & - & $\begin{array}{c}\text { Q: DBC- } \\
\mathrm{T}\end{array}$ & - \\
\hline $\begin{array}{l}\text { Rance et al. } \\
\text { (2017) }\end{array}$ & 10 & $\begin{array}{c}\text { Study B } \\
14.9(1.2) \\
13-16\end{array}$ & 100 & I & $\begin{array}{c}\text { ASD } \\
\text { V: Prac }\end{array}$ & $\begin{array}{c}\text { Auditory } \\
\text { Dysfunction } \\
100 \% \\
\text { ID } 10 \%\end{array}$ & - & 100 & - & $\begin{array}{c}\text { Q: } \\
\text { ASEBA- } \\
\text { TRF }\end{array}$ & \\
\hline
\end{tabular}




\begin{tabular}{|c|c|c|c|c|c|c|c|c|c|c|c|}
\hline $\begin{array}{l}\text { Roohi et al. } \\
\text { (2009) }\end{array}$ & 43 & $\begin{array}{c}7.85(2.4) \\
5-14\end{array}$ & 100 & $\mathrm{D}$ & $\begin{array}{c}\text { AD 37\% } \\
\text { Asp 30\% } \\
\text { PDD-NOS } \\
40 \% \\
\text { V: Prac-M }\end{array}$ & $\begin{array}{c}\text { Med: Psy } \\
30 \%\end{array}$ & Clinic & 35 & Q: CSI-4 & Q: CSI-4 & - \\
\hline $\begin{array}{l}\text { Ung et al. } \\
\text { (2017) }\end{array}$ & 32 & $\begin{array}{c}7.5(1.4) \\
6-10\end{array}$ & 81.3 & $\mathrm{D}$ & $\begin{array}{c}\text { ASD } \\
\text { V: ADOS, } \\
\text { CARS, SCQ }\end{array}$ & ID $35 \%$ & Clinic & - & $\begin{array}{c}\text { Q: } \\
\text { ASEBA- } \\
\text { CBCL }\end{array}$ & $\begin{array}{c}\text { Q: } \\
\text { ASEBA- } \\
\text { TRF }\end{array}$ & - \\
\hline $\begin{array}{c}\text { Weisbrot et } \\
\text { al. }(2005)\end{array}$ & 301 & $\begin{array}{c}8.3(1.9) \\
6-12\end{array}$ & 84 & $\mathrm{D}$ & $\begin{array}{c}\text { AD 34\% } \\
\text { Asp, } 27 \% \\
\text { PDD-NOS } \\
39 \% \\
\text { V: Prac-M }\end{array}$ & Med: $38 \%$ & Clinic & 17 & Q: CSI-4 & Q: CSI-4 & - \\
\hline
\end{tabular}

${ }^{1}$ Where multiple samples or subgroups are described, only the sample and results relevant to this review (e.g., age, diagnosis) are reported on here.

${ }^{2}$ Dash (-) means this information was not stated in paper.

Study design: D descriptive I intervention.

Measures: (Q questionnaire I Interview)

ACAS: Asian Children Anxiety Score - Caretaker version

ADI-S: Anxiety Disorder Interview schedule

ASEBA-CBCL: Achenbach System of Empirically Based Assessment Child Behaviour Checklist (Parent) (Ch: Chinese version)

ASEBA-TRF: Achenbach System of Empirically Based Assessment Teacher Report Form

ASI: Adolescent Symptom Inventory - Fourth Edition

BASC: Behavior Assessment System for Children (TRS: Teacher Report Form)

CASI: Child and Adolescent Symptom Inventory

CCBRS: Conners Comprehensive Behaviour Rating Scales

CSI: Child Symptom Inventory

SCAS: Spence Child Anxiety Inventory (P parent, S self-report)

SAICA: Social Adjustment Inventory for Children and Adolescents

SCARED: Screen for Child Anxiety Related Disorders

SWQ: Social Worries Questionnaire

YSI: Youth Symptom Inventory-Fourth Edition 
Diagnoses:

ASD: Autism Spectrum Disorder

AD: Autistic Disorder

Asp: Asperger's

Com: Community diagnostic reports

Ed.: Educational diagnosis

PDD-NOS: Pervasive Developmental Disorder - Not Otherwise Specified

HFASD: High Functioning Autism (Spectrum Disorder)

DK: Don't know

\section{Verification:}

ASDS: Asperger Syndrome Diagnostic Scale

ADOS: Autism Diagnostic Observation Schedule

ADI: Autism Diagnostic Interview/Autism Diagnostic Interview-Revised

MDA: Multidisciplinary assessment

Prac: Practitioner or clinician diagnosis (sources of information may not be stated)

Prac-M: Practitioner or clinician diagnosis with a range of sources of information

SRS: Social Responsiveness Scale

\section{Medication:}

Med: Prescribed medication (not specified)

Psy: Psychotropic Medication 
Table 3

Studies Reporting Means and Standard Deviations on Comparable Multi-Informant Measures of Anxiety

Anxiety subscale score

\begin{tabular}{|c|c|c|c|c|}
\hline Study & Measure & Parent & Teacher & Child \\
\hline Barnhill et al. (2000) & BASC & $\begin{array}{c}\mathrm{N}=20 \\
59.6(13.4)\end{array}$ & $\begin{array}{c}\mathrm{N}=20 \\
60.1(7.91)\end{array}$ & $\begin{array}{c}\mathrm{N}=20 \\
47.2(10.2)\end{array}$ \\
\hline Chandler et al. (2016) & $\mathrm{DBC}$ & $\begin{array}{c}\mathrm{N}=277 \\
7.8(4.2)\end{array}$ & $\begin{array}{l}\mathrm{N}=228 \\
3.4(2.6)\end{array}$ & - \\
\hline Clarke et al. (2017) & SCAS & $\begin{array}{c}\mathrm{N}=14 \\
\text { Pre: } 34.04(12.2) \\
\text { Post: } 27.9(9.6)\end{array}$ & - & $\begin{array}{l}\quad \mathrm{N}=14 \\
\text { Pre: } 33.9(11.4) \\
\text { Post: } 33.9(6.4)\end{array}$ \\
\hline Drmic et al. (2017) & SCARED & $\begin{array}{l}\quad \mathrm{N}=35 \\
\text { Pre: } 23.1(11.8) \\
\text { Post: } 19.5(9.6)\end{array}$ & - & $\begin{array}{l}\quad \mathrm{N}=35 \\
\text { Pre: } 26.7(13.3) \\
\text { Post: } 19.6(11.3)\end{array}$ \\
\hline $\begin{array}{l}\text { Foley Nicpon et al. } \\
(2010)\end{array}$ & BASC & $\begin{array}{c}\mathrm{N}=52 \\
56.4(13.3)\end{array}$ & $\begin{array}{c}\mathrm{N}=55 \\
56.0(15.0)\end{array}$ & $\begin{array}{c}\mathrm{N}=45 \\
56.0(15.0)\end{array}$ \\
\hline Gadow et al. (2008a) & CSI & $\begin{array}{c}\mathrm{N}=238 \\
\text { GAD: } 5.1(3.8) \\
\text { SpPhob: } 1.0(1.1)\end{array}$ & $\begin{array}{c}\mathrm{N}=238 \\
\text { GAD: } 4.5(3.3) \\
\text { SpPhob: } 0.5(0.8)\end{array}$ & - \\
\hline Gadow et al. (2005) & CSI & $\begin{array}{c}\mathrm{N}=284 \\
\text { GAD: } 4.7(3.7) \\
\text { SpPhob: } 1.0(0.9)\end{array}$ & $\begin{array}{c}\mathrm{N}=284 \\
\text { GAD: } 4.1(3.2) \\
\text { SpPhob: } 0.5(0.8)\end{array}$ & - \\
\hline Gadow et al. (2009a) & CSI & $\begin{array}{c}\mathrm{N}=87 \\
\text { GAD: } 5.2(3.7) \\
\text { SpPhob: } 0.9(0.9)\end{array}$ & $\begin{array}{c}\mathrm{N}=79 \\
\text { GAD: } 5.3(3.5) \\
\text { SpPhob: } 0.5(0.8)\end{array}$ & - \\
\hline Gadow et al. (2009b) & CSI & $\begin{array}{c}\mathrm{N}=67 \\
\text { GAD: } 2.8(2.7)\end{array}$ & $\begin{array}{c}\mathrm{N}=67 \\
\text { GAD: } 2.7(2.3)\end{array}$ & - \\
\hline Gadow et al. (2010) & CSI & $\begin{array}{c}\mathrm{N}=67 \\
\text { GAD: } 2.8(2.7)\end{array}$ & $\begin{array}{c}\mathrm{N}=67 \\
\text { GAD: } 2.7(2.3)\end{array}$ & - \\
\hline $\begin{array}{l}\text { Hammond and } \\
\text { Hoffman (2014) }\end{array}$ & ASI/YSI & $\begin{array}{c}\mathrm{N}=14 \\
\text { GAD: } 73.9(6.9) \\
\text { Sep/Panic } 67.1(9.2)\end{array}$ & $\begin{array}{c}\mathrm{N}=7 \\
\text { GAD: } 75.1(3.2)\end{array}$ & $\begin{array}{c}\mathrm{N}=14 \\
\text { GAD: } 55.1(6.4) \\
\text { Sep/Panic } 65.4(12.6)\end{array}$ \\
\hline Hurtig et al. (2009) & ASEBA & $\begin{array}{c}\mathrm{N}=46 \\
\text { Anx/dep: } 5.2(4.3)\end{array}$ & $\begin{array}{c}\mathrm{N}=23 \\
\text { Anx/dep: } 5.8 \text { (5.2) }\end{array}$ & $\begin{array}{c}\mathrm{N}=46 \\
\text { Anx/dep: } 6.5(6.3)\end{array}$ \\
\hline Luxford et al. (2017) & $\begin{array}{l}\text { SCAS; } \\
\text { SWQ }\end{array}$ & $\begin{array}{c}\mathrm{N}=18 \text { Pre, } \mathrm{N}=15 \text { Post } \\
\text { SCAS: } \\
\text { Pre: } 47.6(16.3) \\
\text { Post (2): } 31.9(14.9)\end{array}$ & $\begin{array}{c}\mathrm{N}=18 \\
\text { SWQ } \\
\text { Pre: } 11.3(3.6) \\
\text { Post (2): } 8.0(4.4)\end{array}$ & $\begin{array}{c}\mathrm{N}=18 \\
\text { SCAS } \\
\text { Pre: } 40.5(16.9) \\
\text { Post (2): } 27.5(14.7) \\
\text { SWQ: } \\
\text { Pre: } 12.3(4.7) \\
\text { Post (2): } 8.8(4.4)\end{array}$ \\
\hline
\end{tabular}


Matsushima et al. (2008)

McDonald et al. (2016)

Ooi et al. (2008)

Ooi et al. (2014)

Pearson et al. (2012)

Ung et al. (2017)
ASEBA

T score

$\mathrm{N}=36$

$\mathrm{N}=34$

Anx/dep 65.0 (9.2)

$\mathrm{N}=118$

55.43 (12.59)

Intervention $\mathrm{N}=6$

Pre: 20.1 (6.9)

Post: 22.0 (9.1)

$$
\mathrm{N}=86
$$

Anx/dep 5.3 (4.4)

$\mathrm{N}=86$

CCBRS

Anxious/shy

$62.5(14.8)$

$\mathrm{N}=32$

ASEBA
Intervention $\mathrm{N}=6$

Pre: 40.6 (20.8)

Post: 33.3 (20.3)
Anx/dep 3.9 (3.7)

$\mathrm{N}=86$

Anxious/Shy

$65.7(13.8)$
$\mathrm{N}=32$

Anx/dep 7.3 (5.7)

Measures:

ASEBA: Achenbach System of Empirically Based Assessment

ASI/YSI: Adolescent /Youth Symptom Inventory

BASC: Behavior Assessment System for Children

CCBRS: Conners Comprehensive Behaviour Rating Scales

CSI: Child Symptom Inventory

DBC: Developmental Behaviour Checklist

SCAS: Spence Child Anxiety Inventory (P parent, S self-report)

SWQ: Social Worries Questionnaire

Subscales:

Anx/dep: Anxious/depressed

GAD: general anxiety

Sep/panic: separation panic

SpPhob: Specific phobia 